\title{
Plasma LH and FSH concentrations in prepubertal beef heifers before and in response to repeated injections of low doses of Gn-RH
}

\author{
B. J. McLeod, W. Haresign, A. R. Peters and G. E. Lamming
}

\section{A.R.C. Research Group on Hormones and Farm Animal Reproduction, University of Nottingham, School of Agriculture, Sutton Bonington, Loughborough, Leicestershire LE12 5RD, U.K.}

\begin{abstract}
Summary. Blood samples were taken at 15 -min intervals from prepubertal beef heifers, 6 aged 4 months and 6 aged 10 months, to determine plasma LH and FSH concentrations. Two animals of each age group were then subjected to 9 consecutive injections of $0 \cdot 5,2.0$ or $5.0 \mu \mathrm{g} \mathrm{Gn-RH}$ at 2-h intervals. LH episodes were evident in all animals before treatment, and in 11/12 heifers occurred at a rate of between 1 and 4 per $24 \mathrm{~h}$. One 10-month old heifer, later detected in oestrus, displayed 10 episodes $/ 24 \mathrm{~h}$. Mean FSH concentrations did not differ significantly between age groups. In all animals, Gn-RH injections induced an episodic pattern of LH secretion which was significantly different between Gn-RH doses, but not between age groups. A distinct episode-like response in FSH concentrations occurred to each Gn-RH injection in only one heifer. These results provide further evidence that the prepubertal period is associated with a lack of pituitary stimulation, rather than an inability to respond to Gn-RH.
\end{abstract}

\section{Introduction}

There appear to be a number of similarities in the endocrine control of the final stages of follicle development in the sheep and the cow, which are reflected in the patterns of episodic LH secretion. Maturation of the preovulatory follicle in both species is associated with a marked increase in the frequency of LH episodes (Baird, 1978; Rahe, Owens, Fleeger, Newton \& Harms, 1980). In addition, periods of ovarian inactivity-seasonal anoestrus in the ewe and post-partum anoestrus in the cow-are associated with a low frequency of LH episodes (Lamming, Wathes \& Peters, 1981; McLeod, Haresign \& Lamming, 1982a, b). Increasing this frequency by repeated administration of low doses of exogenous $\mathrm{Gn}-\mathrm{RH}$ will induce follicular growth, culminating in a normal ovarian cycle in both species (Riley, Peters \& Lamming, 1981; McLeod et al., 1982a, b). The role of FSH in preovulatory follicle development is less well defined. Schams, Schallenberger, Hoffman \& Karg (1977) reported the occurrence of an FSH peak around Day 18 of the oestrous cycle of the cow, which they suggested was a stimulus for follicular growth. However, other workers have failed to detect such an increase (Akbar, Reichert, Dunn, Kaltenbach \& Niswender, 1974; Butler, Katz, Arriola, Milvae \& Foote, 1983). In addition, no relationship is apparent between plasma FSH concentrations and the resumption of ovarian cycles post partum (Schams et al., 1978; Webb, Lamming, Haynes \& Foxcroft, 1980).

It has also been demonstrated that an abrupt increase in the frequency of LH episodes is a prerequisite for the onset of puberty in the sheep, and that precocious puberty can be induced by repeatedly injecting purified LH to increase episode frequency artificially (Ryan \& Foster, 1980). A similar relationship may exist in the heifer; a pulsatile pattern of LH release is evident in 
prepubertal heifers from as early as the first month of life, with episode frequency increasing with age (Schams, Schallenberger, Gombe \& Karg, 1981). Long-term changes in basal LH concentrations have also been reported in prepubertal and pubertal animals. In both the heifer and the ewe lamb, basal plasma LH levels are higher and more variable during the prepubertal period than after the onset of ovarian cyclicity (Gonzalez-Padilla, Wiltbank \& Niswender, 1975; Ryan \& Foster, 1980; Kiser et al., 1981). Schams et al. (1981) reported episodic release of FSH in the prepubertal heifer, with episode frequency increasing with age. However, plasma FSH levels have also been reported to remain relatively constant during the prepubertal and pubertal period in heifers (Gonzalez-Padilla et al., 1975) and ewe lambs (Foster, Lemons, Jaffe \& Niswender, 1975).

It has not yet been determined whether the low LH episode frequency observed in prepubertal animals is due to an inherently poor response of the juvenile anterior pituitary to endogeneous $\mathrm{Gn}$ $\mathrm{RH}$, or to a low frequency of endogenous Gn-RH secretion. The objective of this trial, therefore, was to monitor endogenous LH and FSH secretion in prepubertal heifers of two ages, and then to assess their response to low doses of exogenous $\mathrm{Gn}-\mathrm{RH}$.

\section{Materials and Methods}

Animals and management. Hereford $\times$ Friesian heifers, 6 aged approximately 4 months (Heifers 16 , mean \pm s.e.m. liveweight $111.7 \pm 3.5 \mathrm{~kg}$ ), and 6 aged approximately 10 months (Heifers $7-12$, mean \pm s.e.m. liveweight $208.3 \pm 8.8 \mathrm{~kg}$ ), were housed indoors under conditions of natural daylength and temperature and observed twice daily for oestrus, from 2 weeks before, until 6 weeks after treatment. All animals were fed concentrates and hay twice daily, with fresh water always available.

Treatment and blood sampling. The heifers of each age were randomly assigned to three treatment groups of equal size. After the insertion of a jugular vein catheter $24 \mathrm{~h}$ earlier, blood samples were collected from all animals at 15-min intervals for $24 \mathrm{~h}$ to monitor endogenous $\mathrm{LH}$ and FSH patterns. Immediately thereafter, each heifer was given 9 successive i.v. injections of $0.5 \mu \mathrm{g}$ (Group 1, Heifers 1, 2, $7 \& 8$ ), $2 \cdot 0 \mu \mathrm{g}$ (Group 2, Heifers 3, 4, $9 \& 10$ ) or $5.0 \mu \mathrm{g}$ (Group 3, Heifers 5, 6, 11 \& 12) Gn-RH (Lutal: Fabwerke Hoechst AG, Frankfurt, West Germany) in $2 \mathrm{ml}$ sterile saline $(9 \mathrm{~g} \mathrm{NaCl} / \mathrm{l})$ at 2-h intervals. Blood sampling at 15 -min intervals was continued until $2 \mathrm{~h}$ after the final $\mathrm{Gn}-\mathrm{RH}$ injection. Throughout the treatment period the blood samples were collected immediately before each $\mathrm{Gn}-\mathrm{RH}$ injection.

LH assay. Plasma LH concentrations were measured by the double-antibody radioimmunoassay method of Webb, Lamming, Haynes, Hafs \& Manns (1977). The limit of sensitivity of the assay within this study was $0.5 \mathrm{ng} \mathrm{NIH-LH-B9}$ equiv./ml plasma, and the inter- and intra-assay coefficients of variation were $12.5 \%$ and $5.6 \%$ respectively. There was negligible cross-reaction with other protein hormones.

Plasma LH concentrations. An LH episode was defined by the criteria previously described (Riley et al., 1981; McLeod et al., 1982b). The maximum LH concentrations attained and the area under each LH episode were used to compare differences in LH secretion between age of heifers during the pretreatment period, and in response to Gn-RH injections. The area under an LH episode included only that area above the mean pretreatment basal concentration (i.e. the mean of all values excluding the endogenous $\mathrm{LH}$ episodes).

FSH assay. Blood samples were assayed for FSH by the heterologous radioimmunoassay of Webb et al. (1980). Within this study the limit of sensitivity of the assay was $10 \cdot 8 \mathrm{ng}$ NIH-FSH-BI equiv./ml plasma and the inter- and intra-assay coefficients of variation were $12.4 \%$ and $8.2 \%$ respectively.

Statistical analysis. The data were analysed by analysis of variance, $\chi^{2}$ analysis or Student's $t$ test, as appropriate. 


\section{Results}

Plasma LH profiles over the 24-h pretreatment period are shown in Text-fig. 1. Mean basal LH concentrations (excluding LH episodes) ranged from 1.34 to $2.66 \mathrm{ng} / \mathrm{ml}$, but were not significantly different between animals or between age groups (see Table 1).

LH episodes were evident in all animals and, with the exception of one heifer, occurred at a frequency of 1-4 episodes $/ 24 \mathrm{~h}$. In the remaining animal (Heifer 7 ) $10 \mathrm{LH}$ episodes were recorded. This animal was detected in oestrus 10 days after the intensive blood sampling period, whereas none of the other 11 heifers displayed oestrus within the ensuing 6 weeks. Although individual LH episodes differed markedly in both the maximum LH concentration attained (range $3 \cdot 0-12 \cdot 3 \mathrm{ng} / \mathrm{ml}$ plasma) and the area under the peak (range 20-172 units), there were no significant differences between animals or between age groups in the mean frequency, amplitude or area of the endogenous LH episodes. Plasma FSH profiles for individual heifers are shown in Text-fig. 2. Mean plasma FSH concentration, over the 24 -h pretreatment period varied widely between animals, ranging from 21.6 to $117.1 \mathrm{ng} / \mathrm{ml}$, but there were no significant differences between the two age groups (Table 1). Although FSH concentrations fluctuated throughout the 24-h pretreatment period in some animals, no circadian patterns were apparent and in other animals plasma concentrations remained relatively constant.
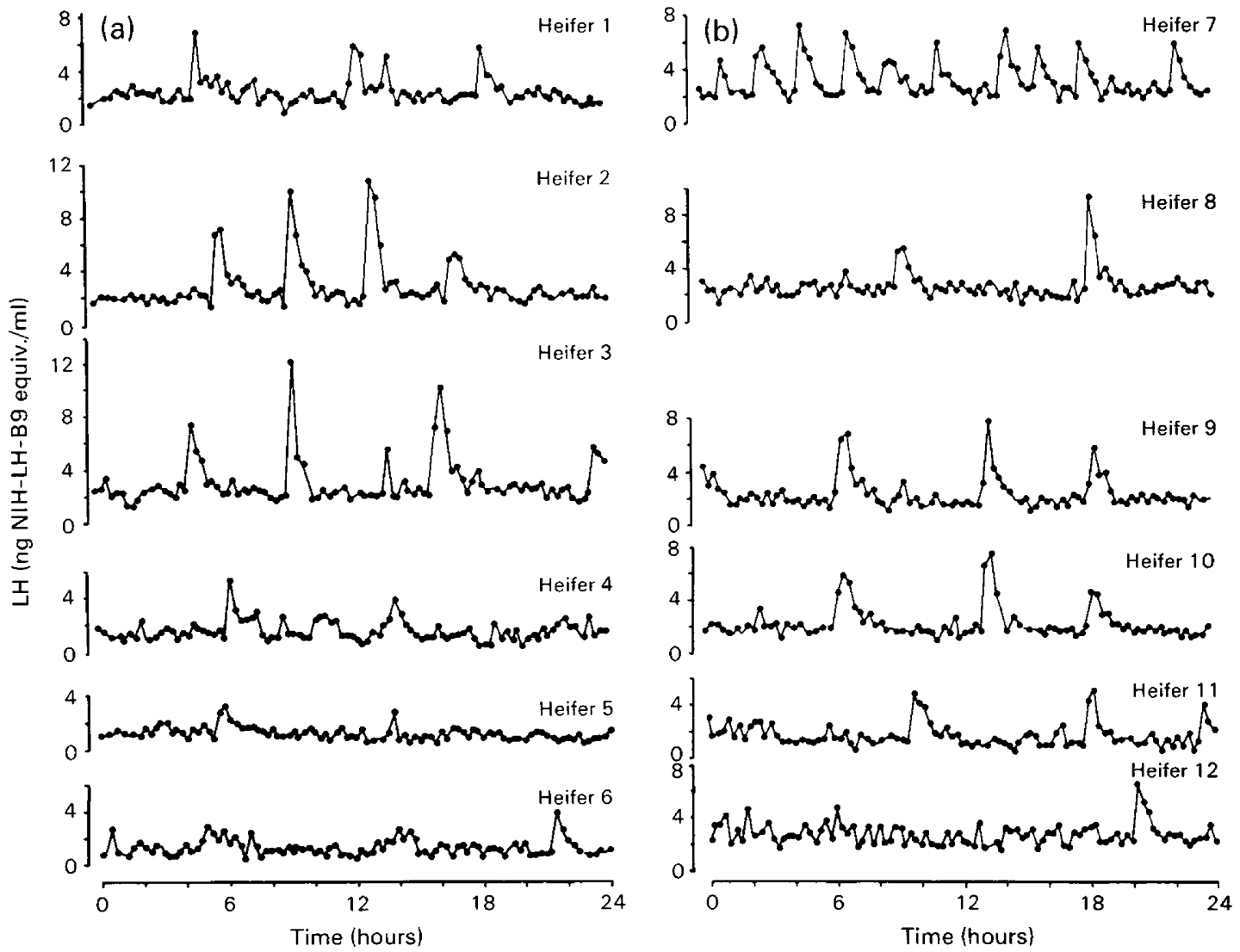

Text-fig. 1. A 24-h profile of plasma LH concentrations in (a) 4-month-old and (b) 10-monthold prepubertal heifers. Blood samples were collected at 15-min intervals. 
Table 1. Liveweights and characteristics of plasma LH and FSH concentrations over the $24 \mathrm{~h}$ pretreatment period in prepubertal beef heifers aged 4 (Nos 1-6) or 10 (Nos 7-12) months

\begin{tabular}{|c|c|c|c|c|c|c|}
\hline Heifer & $\begin{array}{l}\text { Liveweight } \\
\text { (kg) }\end{array}$ & $\begin{array}{l}\text { Mean basal } \\
\text { LH conc.* } \\
\text { (ng/ml) }\end{array}$ & $\begin{array}{l}\text { No. of LH } \\
\text { episodes } / 24 \mathrm{~h}\end{array}$ & $\begin{array}{l}\text { Mean area of } \\
\text { LH episodes } \dagger\end{array}$ & $\begin{array}{l}\text { Mean maximum } \\
\text { conc. LH episodes } \\
(\mathrm{ng} / \mathrm{ml})\end{array}$ & $\begin{array}{l}\text { Mean } \\
\text { FSH conc. } \\
(\mathrm{ng} / \mathrm{ml})\end{array}$ \\
\hline 1 & $108 \cdot 0$ & $2 \cdot 17$ & 3 & 55 & $6 \cdot 3$ & $21 \cdot 59$ \\
\hline 2 & $110 \cdot 5$ & $2 \cdot 25$ & 4 & 138 & $8 \cdot 60$ & $21 \cdot 59$ \\
\hline 3 & $123 \cdot 5$ & 2.66 & 4 & 112 & $10 \cdot 10$ & $65 \cdot 34$ \\
\hline 4 & $106 \cdot 0$ & 1.55 & 3 & 56 & $4 \cdot 27$ & $58 \cdot 30$ \\
\hline 5 & $102 \cdot 0$ & 1.56 & 1 & 54 & $3 \cdot 60$ & $72 \cdot 20$ \\
\hline 6 & $120 \cdot 5$ & $1 \cdot 34$ & 1 & 36 & $4 \cdot 20$ & $117 \cdot 11$ \\
\hline $\begin{array}{c}\text { Mean } \\
( \pm \text { s.e.m. })\end{array}$ & $111 \cdot 7 \pm 3 \cdot 5$ & $1.93 \pm 0.20$ & $2 \cdot 7 \pm 0 \cdot 6$ & $75 \cdot 2 \pm 16 \cdot 4$ & $6 \cdot 19 \pm 1.06$ & $59 \cdot 36 \pm 14 \cdot 60$ \\
\hline 7 & $250 \cdot 0$ & $2 \cdot 24$ & 10 & 60 & $6 \cdot 00$ & $41 \cdot 56$ \\
\hline 8 & $204 \cdot 0$ & $2 \cdot 31$ & 2 & 97 & $7 \cdot 40$ & $115 \cdot 85$ \\
\hline 9 & $202 \cdot 5$ & 1.84 & 3 & 109 & 6.83 & 68.75 \\
\hline 10 & 198.5 & 1.72 & 3 & 115 & $6 \cdot 13$ & $91 \cdot 55$ \\
\hline 11 & $207 \cdot 5$ & 1.75 & 3 & 72 & $5 \cdot 20$ & $32 \cdot 30$ \\
\hline 12 & 188.0 & $2 \cdot 60$ & 1 & 69 & $2 \cdot 60$ & $68 \cdot 18$ \\
\hline Mean & & & & & & \\
\hline ( \pm s.e.m.) & $208 \cdot 2 \pm 8 \cdot 8$ & $2 \cdot 07 \pm 0 \cdot 15$ & $2.4 \pm 0.4 \ddagger$ & $87 \cdot 0 \pm 9 \cdot 4$ & $5.69 \pm 0.69$ & $69 \cdot 70 \pm 12 \cdot 65$ \\
\hline
\end{tabular}

The $L H$ response to i.v. injections of a given dose of $\mathrm{Gn}-\mathrm{RH}$ was not significantly influenced by age of animal. The mean ( \pm s.e.m.) LH response to each Gn-RH dose is shown in Text-fig. 3 and the characteristics of the induced LH responses are given in Table 2. At the two higher Gn-RH doses, a well-defined rise in plasma concentrations, closely resembling an endogenous LH episode, occurred in response to each of the 9 injections in all animals. However, at the low dose level only 1 of the 4 treated heifers produced a well-defined response to each injection, while the other 3 animals produced a response to some, but not all, of the $\mathrm{Gn}-\mathrm{RH}$ challenges. This variability is reflected in the less well-defined mean responses apparent in Text-fig. 3(a).

A dose-response relationship was evident when the characteristics of the Gn-RH-induced LH episodes were compared between groups (Table 2$)$, with a significant difference in mean area $(P<$ $0.05)$ between the high $(5.0 \mu \mathrm{g})$ and the low $(0.5 \mu \mathrm{g})$ doses. In 1 of the 4-month-old animals (Heifer 5) there was a distinct, episode-like response in FSH concentration to each injection of Gn-RH. In addition, a similar episodic pattern of FSH release was coincident with some, but not all, Gn-RH injections in 5 other heifers (Heifers 4, 6, 7, 9 \& 12). However, mean FSH concentrations over the Gn-RH treatment period were not significantly different from pretreatment concentrations (Table 3).

Table 2. Mean ( \pm s.e.m.) plasma LH concentrations in prepubertal beef heifers in response to 9 i.v. injections of $0.5,2.0$ or $5.0 \mu \mathrm{g} \mathrm{Gn-RH}$

\begin{tabular}{ccccc}
\hline $\begin{array}{c}\text { Treatment } \\
\text { group }\end{array}$ & $\begin{array}{c}\text { No. of } \\
\text { heifers }\end{array}$ & $\begin{array}{c}\text { Gn-RH } \\
\text { dose } \\
(\mu \mathrm{g} / \mathrm{inj})\end{array}$ & $\begin{array}{c}\text { Mean area } \\
\text { of LH episodes } \\
\text { (arbitrary units) }\end{array}$ & $\begin{array}{c}\text { Mean max. conc. } \\
\text { of LH episodes } \\
(\mathrm{ng} / \mathrm{ml})\end{array}$ \\
\hline 1 & 4 & $0 \cdot 5$ & $77 \pm 17^{\mathrm{a}}$ & $5 \cdot 42 \pm 0 \cdot 60$ \\
2 & 4 & $2 \cdot 0$ & $116 \pm 9^{\mathrm{ab}}$ & $6 \cdot 75 \pm 0.66$ \\
3 & 4 & $5 \cdot 0$ & $139 \pm 16^{\mathrm{b}}$ & $7 \cdot 01 \pm 0 \cdot 30$ \\
\hline
\end{tabular}

Within columns means with different superscripts are significantly different, $P<0.05$. 
$+1+1+1+1$

$80+(a)$

Heifer 1

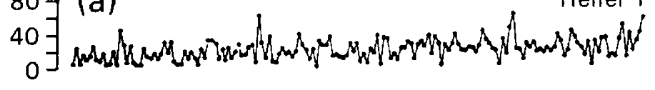
(b) $\quad+1+1+1+1+\frac{1}{4}+\frac{1}{4}$

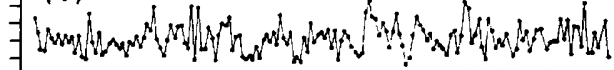
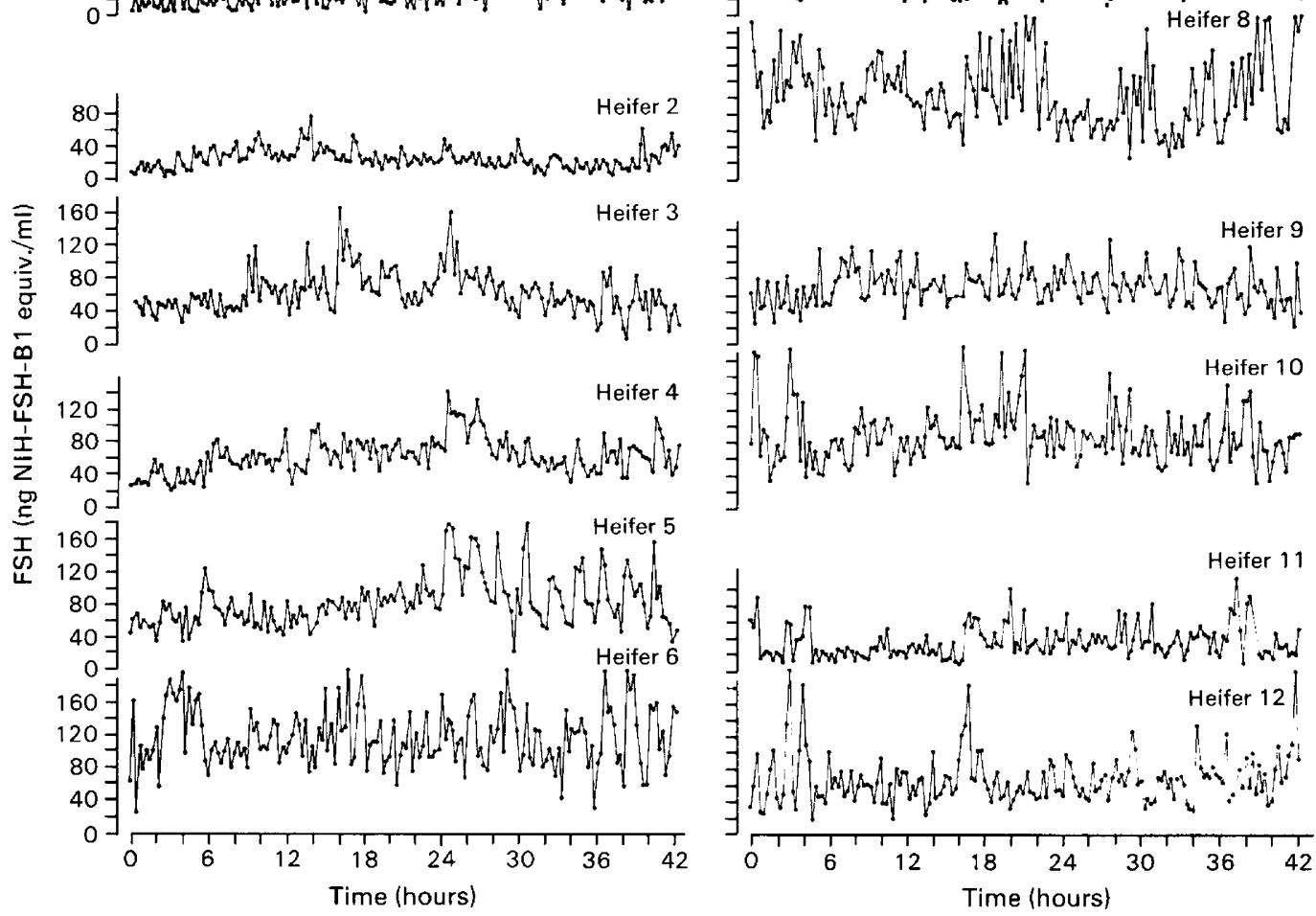

Text-fig. 2. Plasma FSH concentrations in (a) 4-month-old and (b) 10-month-old prepubertal heifers throughout a $24-\mathrm{h}$ pretreatment period and in response to 2 -h injections (arrows) of $0.5 \mu \mathrm{g}$ (Heifers 1, 2, $7 \& 8$ ), $2.0 \mu \mathrm{g}$ (Heifers 3, 4, $9 \& 10$ ) or $5.0 \mu \mathrm{g}$ (Heifers $5,6,11$ \& 12) Gn-RH. Blood samples were collected at $15-$ min intervals.

Table 3. Mean ( \pm s.e.m.) plasma FSH concentrations in prepubertal beef heifers before and in response to 9 i.v. injections of $0.5,2.0$ or 5.0 $\mu \mathrm{g}$ Gn-RH

\begin{tabular}{ccccc}
\hline $\begin{array}{c}\text { Treatment } \\
\text { group }\end{array}$ & $\begin{array}{c}\text { No. of } \\
\text { heifers }\end{array}$ & $\begin{array}{c}\text { Gn-RH } \\
\text { dose } \\
\text { (ng/injection) }\end{array}$ & $\begin{array}{c}\text { Pretreatment } \\
\text { FSH conc. } \\
\text { (ng/ml) }\end{array}$ & $\begin{array}{c}\text { FSH conc. during } \\
\text { Gn-RH treatment } \\
\text { (ng/ml) }\end{array}$ \\
\hline 1 & 4 & $0 \cdot 5$ & $50 \cdot 7 \pm 19 \cdot 5$ & $55 \cdot 5 \pm 20 \cdot 3$ \\
2 & 4 & $2 \cdot 0$ & $69 \cdot 9 \pm 5 \cdot 8$ & $72 \cdot 1 \pm 7 \cdot 0$ \\
3 & 4 & $5 \cdot 0$ & $72 \cdot 5 \pm 17 \cdot 4$ & $83 \cdot 1 \pm 17 \cdot 8$ \\
\hline
\end{tabular}

\section{Discussion}

Before Gn-RH treatment an episodic pattern of $\mathrm{LH}$ release was evident in all 12 prepubertal heifers in this study, confirming the report of Schams et al. (1981). The magnitude and duration of the LH episodes detected in these animals were similar to those occurring in mature cows (Rahe et al., 1980; Riley et al., 1981). In addition, with the exception of Heifer 7, the frequency of endogenous 


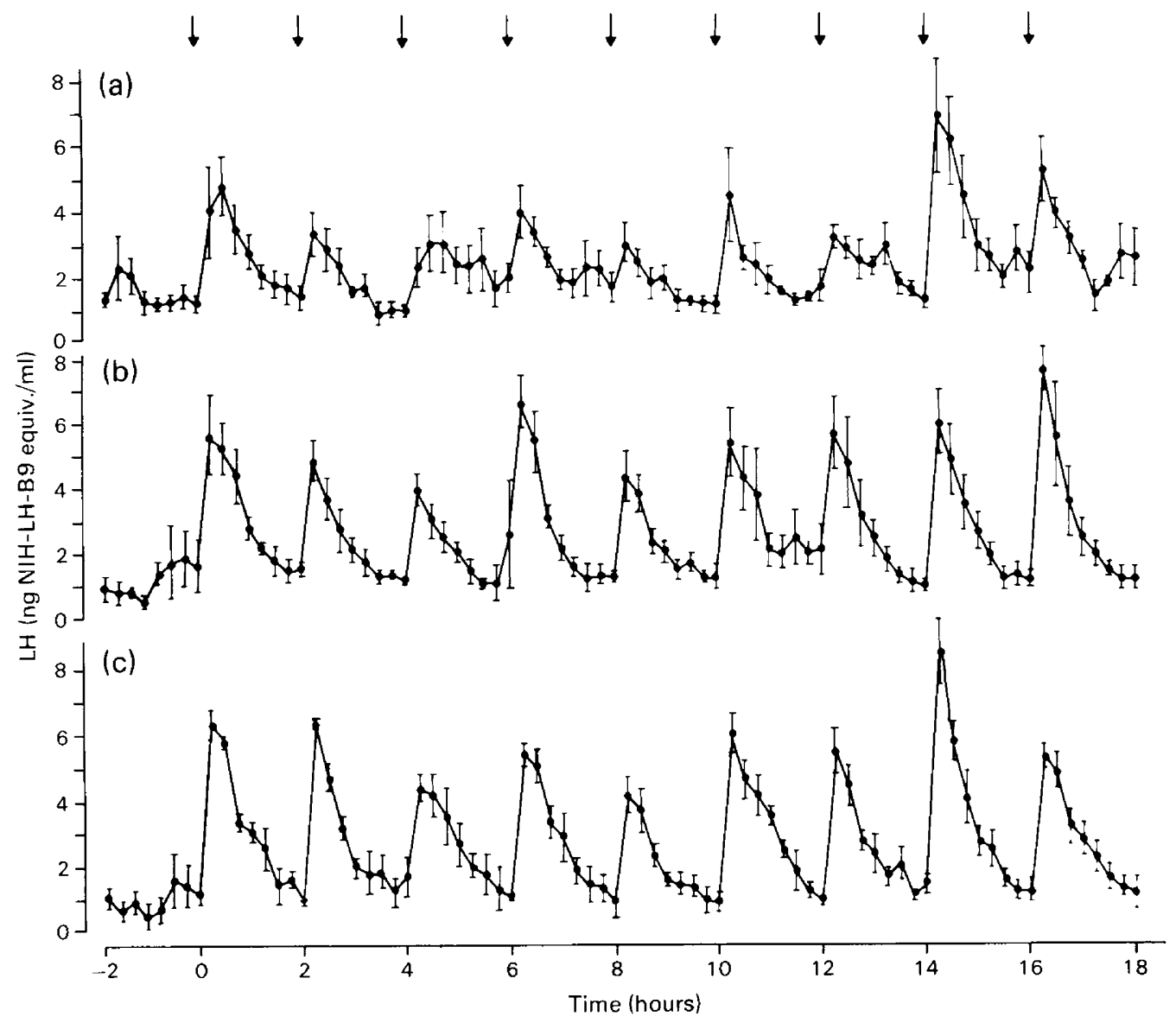

Text-fig. 3. Mean ( \pm s.e.m.) plasma LH concentrations in prepubertal heifers before and in response to 9 consecutive i.v. injections (arrows) of (a) $0.5 \mu \mathrm{g}$, (b) $2.0 \mu \mathrm{g}$ or (c) $5.0 \mu \mathrm{g} \mathrm{Gn-RH}$.

LH episodes occurring in heifers of both ages was comparable to that reported for mature, acyclic cows, but significantly less than that observed during the follicular phase of the oestrous cycle (Rahe et al., 1980; Lamming et al., 1981). In Heifer 7, which was detected in oestrus shortly after treatment, the endogenous LH episode frequency was significantly higher than that in all of the other heifers and was equivalent to that seen in naturally-cyclic cows during the follicular phase of the oestrous cycle. These results support the suggestion of Rahe et al. (1980) that ovarian activity is directly related to LH episode frequency. Such a relationship is evident in the sheep, with an increase in LH episode frequency immediately preceding the onset of puberty (Ryan \& Foster, 1980). However, in contrast to the findings of Schams et al. (1981), LH episode frequency in prepubertal heifers in this trial did not increase with age. The mean baseline plasma LH concentrations (excluding LH episodes) measured, were similar for heifers of both ages, and were comparable to those previously reported (Gonzalez-Padilla et al., 1975; Kiser et al., 1981). Furthermore, these basal levels were consistently higher than those measured simultaneously in this laboratory with the same radioimmunoassay system in mature, post-partum acyclic cows (mean \pm s.e.m. $0.79 \pm 0.09 \mathrm{ng} / \mathrm{ml}$, range $0.55-1.07 \mathrm{ng} / \mathrm{ml}, \mathrm{N}=6)(\mathrm{M}$. W. Fisher \& G. E. Lamming, unpublished data), which suggests that the attainment of sexual maturity is also related to the establishment of lower and more stable basal LH concentrations. 
The $\mathrm{LH}$ response to repeated injections of low doses of Gn-RH in prepubertal heifers in this trial suggests the existence of a fully-functional anterior pituitary, even at 4 months of age. The nonlinear nature of the dose-response relationship is also in agreement with data from the sheep (McLeod et al., 1982b). It would appear that a $0.5 \mu \mathrm{g} \mathrm{Gn-RH}$ injection is near the threshold dose necessary to evoke an LH response, as only one of the 4 heifers treated with this dose responded to every Gn-RH injection, and the mean amplitude and area of the induced episodes were similar to those of naturally-occurring episodes during the pretreatment period. In contrast, a pituitary response was recorded after each $\mathrm{Gn}-\mathrm{RH}$ injection in all animals treated with the two higher doses, and the induced episodes were of greater magnitude than naturally-occurring episodes (see Tables 1 \& 2).

From a statistical point of view, with only 2 heifers per Gn-RH dose, it was not possible to determine an age effect in the $\mathrm{LH}$ response. However, the absence of any dose-response differences between the two age groups is still surprising, especially with the 2 -fold difference in mean liveweight. This suggests that, at least in the prepubertal animal, sensitivity to low doses of Gn-RH increases with increasing age. In contrast, the mean maximum LH concentration of episodes attained in heifers in this study in response to the $5 \mu \mathrm{g} \mathrm{Gn-RH}$ dose (mean \pm s.e.m., $7 \cdot 01 \pm 0 \cdot 23$ $\mathrm{ng} / \mathrm{ml}$, range $4.5-12.0 \mathrm{ng} / \mathrm{ml}, 36$ episodes) was significantly greater $(P<0.001)$ than that reported for mature, acyclic post-partum cows (mean \pm s.e.m., $2.63 \pm 0.16 \mathrm{ng} / \mathrm{ml}$, range $1.3-6.2 \mathrm{ng} / \mathrm{ml}, 35$ episodes) (Riley et al., 1981).

The mean plasma concentrations and the between-animal variation in FSH levels recorded during the pretreatment period in this trial are comparable to those reported earlier for the prepubertal heifer (Gonzalez-Padilla et al., 1975; Schams et al., 1981). Indeed, the pattern of FSH secretion in the prepubertal animal appears to be similar to that in the mature cow (Akbar et al., 1974; Webb et al., 1980; Riley et al., 1981). This is substantiated by the absence of any marked differences in plasma FSH concentrations in the one animal (Heifer 7) detected in oestrus. However, in contrast to the findings of Schams et al. (1981), FSH secretion during the pretreatment period in this trial could not be described as episodic. Although FSH 'episodes' were detectable in some animals, these were largely camouflaged by fluctuation in baseline concentrations. However, the administration of Gn-RH at 2-h intervals led to an episodic pattern of release of FSH in some heifers. This is most clearly demonstrated in Heifer 5 in which FSH release was dramatically changed by $\mathrm{Gn}-\mathrm{RH}$ treatment. It is not clear why only one animal responded to each $\mathrm{Gn}-\mathrm{RH}$ injection, but as this heifer was receiving the highest dose on a per $\mathrm{kg}$ liveweight basis, it may be that the other heifers were receiving sub-threshold doses. Indeed, the other 4-month-old animal treated with this dose of Gn-RH $(5.0 \mu \mathrm{g} /$ injection) produced episodic responses to some injections, whereas neither of the 10-month-old heifers responded. Furthermore, the $5 \mu \mathrm{g}$ dose of Gn-RH also failed to induce episodic FSH release in mature, post-partum acyclic cows (Riley et al., 1981). These results indicate that the threshold dose of Gn-RH necessary to evoke FSH release is markedly higher than that necessary for $\mathrm{LH}$ release.

Within the limited duration of Gn-RH administration in this study ( 9 consecutive injections at 2-h intervals) there was no evidence of pituitary refractoriness; indeed a constancy of $\mathrm{LH}$ response was evident, similar to that observed in seasonally anoestrous ewes (McLeod et al., 1982a, b). The duration of Gn-RH treatment was much less than that required to induce ovarian cycles in mature acyclic beef cows (Riley et al., 1981), and it has yet to be determined whether an extended period of Gn-RH administration would eventually result in preovulatory-type $\mathrm{LH}$ release, and ovulation in the prepubertal heifer. The artificial elevation of LH episode frequency may itself not be sufficient to promote preovulatory follicle growth because early follicle development may be lacking, particularly at the younger ages. However, it has been demonstrated that prepubertal heifers as young as 3 months of age are able to produce a preovulatory LH surge in response to administration of oestradiol (Staigmiller, Short \& Bellows, 1979).

These data suggest that the low frequency of LH episodes in prepubertal heifers is due to hypothalamic inactivity rather than to the inability of the pituitary to respond to hypothalamic 
secretions. Whether this hypothalamic inactivity is related to hypersensitivity to negative feedback mechanisms, as has been suggested for the ewe lamb (Ryan \& Foster, 1980), has yet to be established.

We thank the A.R.C. and Hoechst Pharmaceuticals for financial support; Hoechst Pharmaceuticals for supplies of synthetic Gn-RH and the National Institutes of Health for standard LH and FSH.

\section{References}

Akbar, A.M., Reichert, L.E., Dunn, T.G., Kaltenbach, C.C. \& Niswender, G.D. (1974) Serum levels of follicle-stimulating hormone during the bovine estrous cycle. J. Anim. Sci. 39, 360-365.

Baird, D. T. (1978) Pulsatile secretion of LH and ovarian estradiol during the follicular phase of the sheep estrous cycle. Biol. Reprod. 18, 359-364.

Butler, W.R., Katz, L.S., Arriola, J., Milvae, R.A. \& Foote, R.H. (1983) On the negative feedback regulation of gonadotropins in castrate and intact cattle with comparison of two FSH radioimmunoassays. $J$. Anim. Sci. 56, 919-929.

Foster, D.L., Lemons, J.A., Jaffe, R.B. \& Niswender, G.D. (1975) Sequential patterns of circulating luteinizing hormone and follicle-stimulating hormone in female sheep from early post-natal life through the first estrous cycles. Endocrinology 97, 985-994.

Gonzalez-Padilla, E., Wiltbank, J.N. \& Niswender, G.D. (1975) Puberty in beef heifers. 1. The interrelationship between pituitary, hypothalamic and ovarian hormones. J. Anim. Sci. 40, 1091-1104.

Kiser, T.E., Kraeling, R.R., Rampacek, G.B., Landmeier, B.J., Candle, A.B. \& Chapman, D.B. (1981) Luteinizing hormone secretion before and after ovariectomy in prepubertal and pubertal beef heifers. J. Anim. Sci. 53, 1545-1550.

Lamming, G.E., Wathes, D.C. \& Peters, A.R. (1981) Endocrine patterns of the post-partum cow. $J$. Reprod. Fert., Suppl. 30, 155-170.

McLeod, B.J., Haresign, W. \& Lamming, G.E. (1982a) The induction of ovulation and luteal function in seasonally anoestrous ewes treated with small-dose multiple injections of Gn-RH. J. Reprod. Fert. 65, 215-221.

McLeod, B.J., Haresign, W. \& Lamming, G.E. (1982b) Response of seasonally anoestrous ewes to small-dose multiple injections of $\mathrm{Gn}-\mathrm{RH}$ with and without progesterone pretreatment. J. Reprod. Fert. 65, 223-230.

Rahe, C.H., Owens, R.E., Fleeger, J.L., Newton, H.J. \& Harms, P.G. (1980) Pattern of plasma luteinizing hormone in the cyclic cow: dependence upon the period of the cycle. Endocrinology 107, 498-503.

Riley, G.M., Peters, A.R. \& Lamming, G.E. (1981) Induction of pulsatile $\mathrm{LH}$ release, FSH release and ovulation in post-partum acyclic beef cows by repeated small doses of Gn-RH. J. Reprod. Fert. 63, 559-565.

Ryan, K.D. \& Foster, D.L. (1980) Neuroendocrine mechanisms involved in onset of puberty in the female: concepts derived from the lamb. Fedn Proc. Fedn Am. Socs exp. Biol. 39, 2372-2377.

Schams, D., Schallenberger, E., Hoffman, B. \& Karg, H. (1977) The oestrous cycle of the cow: hormonal parameters and time relationships concerning oestrus, ovulation and electrical resistance of the vaginal mucus. Acta endocr., Copenh. 86, 180-192.

Schams, D., Schallenberger, E., Menzer, Ch., Stangl, J., Zottmeier, K., Hoffman, B. \& Karg, H. (1978) Profiles of $\mathrm{LH}, \mathrm{FSH}$ and progesterone in post-partum dairy cows and their relationship to the commencement of cyclic functions. Theriogenology 10, 453 468 .

Schams, D., Schallenberger, E., Gombe, S. \& Karg, H. (1981) Endocrine patterns associated with puberty in male and female cattle. J. Reprod. Fert., Suppl. 30, 103-110.

Staigmiller, R.B., Short, R.E. \& Bellows, R.A. (1979) Induction of LH surges with $17 \beta$ oestradiol in prepubertal beef heifers: an age dependant response. Theriogenology 11, 453-459.

Webb, R., Lamming, G.E., Haynes, N.B., Hafs, H.D. \& Manns, J.G. (1977) Response of cyclic and postpartum suckled cows to injections of synthetic LHRH. J. Reprod. Fert. 50, 203-210.

Webb, R., Lamming, G.E., Haynes, N.B. \& Foxcroft, G.R. (1980) Plasma progesterone and gonadotrophin concentrations and ovarian activity in post-partum dairy cows. J. Reprod. Fert. 59, 133-143.

Received 29 April 1983 